KONSTAN
JURNAL FISIKA DAN PENDIDIKAN FISIKA
Volume 5, Nomor 2, Desember 2020
E-ISSN : 2460-9129 dan P-ISSN : 2460-9110
http://jurnalkonstan.ac.id/index.php/jurnal

\title{
PERBANDINGAN PEMAHAMAN KONSEP INTERPRETASI FISIKA ANTARA MODEL PEMBELAJARAN INKUIRI TERBIMBING DAN INKUIRI BEBAS TERMODIFIKASI
}

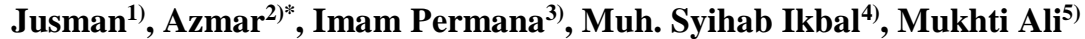 \\ 1,3,4,5) Jurusan Pendidikan Fisika, Fakultas Tarbiyah dan Keguruan, UIN Alauddin \\ Makassar, Indonesia \\ ${ }^{2)}$ Program Studi Tadris Fisika Fakultas Tarbiyah dan Keguruan, Universitas Islam \\ Negeri Mataram, Mataram, Indonesia
}

\begin{tabular}{l}
\hline Info Artikel \\
\hline Sejarah Artikel: \\
Diterima 19 Desember \\
2020 \\
Disetujui 30 Desember \\
2020 \\
Dipublikasikan 31 \\
Desember 2020
\end{tabular}

Kata Kunci:

Contextual Teaching Learning, Kemampuan Argumentasi

\begin{tabular}{|c|}
\hline Abstract \\
\hline 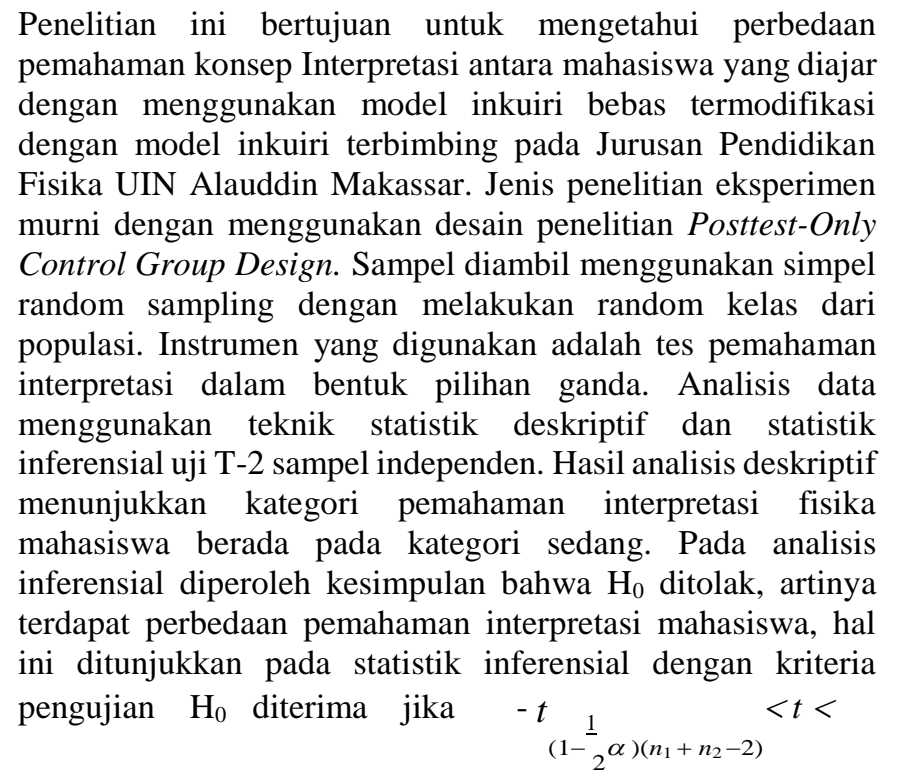 \\
\hline$t_{\left(1-\frac{1}{2} \alpha\right)\left(n_{1}+n_{2}-2\right)}$ dan untuk harga-harga t lainnya $\mathrm{H}_{0}$ ditolak. \\
\hline $\begin{array}{l}\text { Nilai T-test yang diperoleh } 3,33 \text { sedang } t_{0,975}=1,98 \text {, sehingga } \\
t_{\text {hitung }}>\mathrm{t}_{\text {tabel }}(3,33<1,98) .\end{array}$ \\
\hline
\end{tabular}

(C) 2020 Universitas Islam Negeri Mataram 


\section{PENDAHULUAN}

Pencapaian nilai Trends in International Mathematics and Science Study (TIMMS) mahasiswa Indonesia untuk bidang Matematika dan Sains masih tergolong rendah. Hasil tes TIMSS 2003 yang dikoordinir oleh The International for Evaluation of Education Achievement (IEA) menempatkan mahasiswa Indonesia di peringkat 36 penguasaan Sains dari 45 negara yang terlibat [1]. Data ini diperoleh sekitar 7 tahun yang lalu. Pasti berbeda dengan kondisi pendidikan indonesia saat ini yang mulai dinamis.

Wajah pendidikan di Indonesia saat ini semakin berbenah, sebut saja pendidikan di masa lampau menitik beratkan transfer ilmu dengan mengandalkan pengajar/ pendidik sebagai sumber ilmu yang utama. Peserta didik hanya mendengarkan dan mencatat informasi yang disampaikan oleh pendidik dalam hal ini disebut dengan teacher centre. Wajah pendidikan saat ini telah memulai menerapkan pendidik hanya sebagai fasilitator dan peserta didik yang aktif menggali informasi dan mengkonstuk pengetahuannya sendiri melalui pengalamanpengalaman yang diperoleh dalam menggali informasi.

Pengetahuan sangat erat kaitannya dengan proses pembelajaran. Sebab itu kompetensi siswa tercapai banyak diperoleh dalam proses pembelajaran dalam hal ini perkuliahan bagi mahasiswa. Salah satu mata kuliah yang memerlukan pemahaman dasar yang kuat adalah mata kuliah fisika dasar yang merupakan pondasi dasar pengetahuan fisika untuk melanjutkan ke pengetahuan fisika yang lebih mendalam. Dilain sisi fisika dasar perlu kedalaman pemahaman yang mumpuni karena fisika dasar inilah yang banyak digunakan dalam proses pembelajaran di sekolah saat mahasiswa masuk pada dunia pendidikan sebagai guru di satuan pendidikan sekelah menengah. Mata kuliah fisika dasar pada dasarnya sangat berkaitan dengan kerja laboratorium.

Model inkuiri adalah model pembelajaran dimana siswa dituntut untuk lebih aktif dalam proses penemuan, penempatan siswa lebih banyak belajar sendiri serta mengembangkan keaktifan dalam memecahkan masalah. Proses inquiri adalah suatu proses khusus untuk meluaskan pengetahuan melalui penelitian. Oleh karena itu model inquiri kadang-kadang disebut juga model ilmiahnya penelitian. Model inquiri adalah model belajar dengan inisiatif sendiri, yang dapat dilaksanakan secara individu atau kelompok kecil. Situasi inquiri yang ideal dalam kelas terjadi, apabila murid-murid merumuskan prinsip baru melalui bekerja sendiri atau dalam grup kecil dengan pengarahan minimal dari dosen atau guru. Peran utama dosen atau guru dalam pelajaran inquiri sebagai modelrator [2] .

Model inquiri merupakan model pengajaran yang berusaha meletakan dasar dan mengembangkan cara befikir ilmiah. Dalam penerapan model ini siswa dituntut untuk lebih banyak belajar sendiri dan berusaha mengembangkan kreatifitas dalam pengembagnaan masalah yang dihadapinya sendiri. Model mengajar inquiri akan menciptakan kondisi belajar yang efektif dan kundusif, serta mempermudah dan memperlancar kegiatan belajar mengajar [3].

Model inquiry dikembangkan dengan beberapa model antara lain inkuiri bebas atau free inquiry, inquiry terbimbing atau guided inquiry atau inkuiri terbimbing, dan modified free inquiry atau inkuiri bebas termodifikasi. Berdasarkan hasil penelitian Schlenker [4]. menunjukkan bahwa latihan inkuiri dapat 
meningkatkan pemahaman sains, produktif dalam berpikir kreatif dan siswa menjadi terampil dalam memperoleh dan menganalisis informasi.

Berdasarkan pendapat para ahli di atas dapat disimpulkan bahwa model inquiri dalam penelitian ini adalahsuatu teknik instruksional dalam proses belajar mengajar siswa diharapkan pada suatu masalah, dan tujuan utama menggunakan model inquiri adalah membantu siswa dalam mengembangkan keterampilan penemuan ilmiah.

Sedangkan asumsi-asumsi yang mendasari model inquiri adalah (1) Keterampilan berpikir kritis dan berpikir dedukatif sangat diperlukan pada waktu mengumpulkan evidensi yang dihubungkan dengan hipotesis yang telah dirumuskan oleh kelompok dan (2) Keuntungan para peserta didik dari pengalaman-pengalaman kelompok di mana mereka berkomunikasi, berbagai tanggung jawab dan bersamasama mencari pengetahuan serta (3) Kegiatan-kegiatan belajar yang disajikan dalam semangat berbagi inquri menambah motivasi dan memajukan partisipasi aktif [5].

Syarat-syarat penerapan model inquiri adalah (1) Merumuskan topik inquiri dengan jelas dan bermanfaat bagi siswa dan (2) Membentuk kelompok yang seimbangn, baik akademik maupun sosial serta (3) Menjelaskan tugas dan menyediakan balikan kepada kelompok-kelompok dengan cara yang responsif dan tepat waktunya. Sekali-kal perlu intervensi oleh guru agar terjadi interaksi antarpribadi yang sehat dan demi kemajuan tugas, Melaksanakan penilaian terhadap kelompok, baik terhadap kemajuan kelompok maupun terhadap hasil-hasil yang dicapai.

Pelaksanaan pembelajaran dengan inkuiri tanpa adanya arahan atau bimbingan akan mengakibatkan kekacauan dalam proses pembelajaran. Sehingga dalam penerapannya siswa harus mendapatkan arahan dari guru atau pendidik yang kemudian diistilahkan dengan model inkuiri terbimbing. Model inkuiri terbimbing adalah model dimana guru yang membimbing siswa dalam membangun pengetahuan dan pemahamannya melalui penyelidikan yang dirancang dengan cermat dan tetap dalam pengawasan [6].

Inkuiri terbimbing merupakan model pembelajaran, dimana dosen lebih banyak memberikan bimbingan kepada mahasiswa dalam proses berinkuiri mulai awal pelaksanaan pembelajaran hingga akhir. Sedangkan model inkuiri bebas termodifikasi, dosen hanya menyiapkan permasalahan selanjutnya mahasiswa menyelesaikan permasalahan melalui proses ekplorasi, pengamatan atau peneitian. Pada model ini mahasiswa diberikan banyak keleluasaan dalam mengkonstruk pemahamannya sendiri terhadap permasalahan yang telah diberikan oleh dosen atau pendidik.

Tingkatan aspek pengetahuan atau kognitif yang diperkenalkan oleh Benyamin S. Bloom memiliki kualitas yang baik untuk menentukan tingkatan kemampuan dan pengetahuan. Salah satu dari tingkatan dasar kemampuan berpikir atau low order thinking adalah pemahaman.

Bloom menyatakan bahwa salah satu tanda seseorang orang mengetahui suatu hal ditandai dengan pemahaman yang dapat disampaikan kepada orang lain abik dari segi kemampuan untuk menyampaikan isi dari suatu subjek atau hal-hal yang berkaitan dengan objek tersebut.Implikasi dari pernyataan tersebut adalah seluruh peserta didik diharapkan untuk memahami suatu konsep agar ketika dihadapkan dengan keadaan di mana peserta didik berkomunikasi, maka peserta didik diharapkan mengetahui apa yang mereka jelaskan baik dalam bahasa verbal, non 
verbal atau bahkan dalam bentuk simbolik sekalipun. Pemahaman yang komprehensif ditandai dengan bentuk penyampaian dengan cara yang berbeda dengan cara yang di dapatkan, karena ada indikasi dari ingatan atau kemampuan menghafal yang harus dihindari. Pandangan ini didasari bahwa ingatan memiliki tingkatan kesulitan yang lebih rendah dibandingkan pemahaman [7].

Bloom membagi ranah kognitif dalam 6 taksonomi dan melatakkan pemahaman lebih tinggi dari pengetahuan. Aspk-aspek pemahaman Bloom membegi aspek pemahaman dalam tiga aspek, yakni Translasi, interpretasi dan ekstrapolasi. Dalam penelitian ini penulis tertarik mengkaji pemahaman interpretasi dengan membandingkan pemahaman Interpretasi yang terbentuk menggunakan model pembelajaran inkuiri terbimbing dan model pembelajaran ikuiri bebas termodifikasi.

Pemahaman interpretasi (kemampuan menafsirkan) adalah kemampuan untuk memahami bahan atau ide yang direkam, diubah, atau disusun dalam bentuk lain. Misalnya dalam bentuk grafik, peta konsep, tabel, simbol, dan sebaliknya. Jika kemampuan menterjemahkan mengandung pengertian mengubah bagian demi bagian, kemampuan menafsirkan meliputi penyatuan dan penataan kembali. Dengan kata lain, menghubungkan bagian-bagian terdahulu dengan bagian-bagian yang diketahui berikutnya. Dalam proses pembelajaran, pemahaman interpretasi terdiri atas beberapa indikator pencapaian yaitu (a) Kemampuan untuk memahami dan menginterpretasikan berbagai bentuk bacaan secara jelas dan mendalam dan (b) Kemampuan untuk membedakan pembenaran atau penyangkalan suatu kesimpulan yang digambarkan dalam suatu data serta (c) Kemampuan untuk membuat batasan (qualification) yang tepat ketika menafsirkan suatu data.

Berdasarkan paparan di atas maka peneliti tertarik untuk menerapkan model inkuiri pada mata kuliah fisika dasar 2. Pada mata kuliah fisika dasar 1 mahasiswa telah melakukan eksperimaen, sehingga syarat untuk melakukan eksperimen pada fisika dasar 2 telah terpenuhi. Dari paparan inilah maka peneliti mengambil judul "Perbandingan Pemahaman konsep interpretasi antara Model Pembelajaran Inkuiri Terbimbing dan Inkuiri Bebas Termodifikasi Mahasiswa Pendidikan Fisika UIN Alauddin Makassar" dengan Tujuan (1) Untuk mengetahui seberapa besar tingkat pemahaman konsep interpretasi fisika dengan menggunakan model pembelajaran inkuiri terbimbing mahasiswa Jurusan Pendidikan Fisika UIN Alauddin Makassar (2) Untuk mengetahui seberapa besar tingkat pemahaman konsep interpretasi fisika dengan menggunakan model pembelajaran inkuiri bebas termodifikasi mahasiswa Jurusan Pendidikan Fisika UIN Alauddin Makassar dan (3) Untuk mengetahui perbedaan pemahaman Interpretasi antara mahasiswa yang diajar dengan menggunakan model pembelajaran inkuiri bebas termodifikasi dengan model inkuiri terbimbing pada Jurusan Pendidikan Fisika UIN Alauddin Makassar.

\section{METODE PENELITIAN}

Jenis penelitian ini adalah penelitian true ekperimen, yaitu merandom semua kelas yang menjadi populasi ( seluruh mahasiswa jurusan pendidikan fisika semister 2 yang terdiri atas 3 kelas) untuk mendapatkan dua kelas untuk kelas inkuiri terbimbing dan kelas inkuiri bebas termodifikasi. selanjutnya kedua kelas tersebut 
dirandom untuk menentukan kelas yang diajar dengan menggunakan model inkuiri terbimbing dan kelas yang diajar dengan menggunakan model inkuiri bebas termodifikasi. Kelas eksperimen diberikan model pembelajaran inkuiri bebas termodifikasi dan kelas kontrol diberikan model pembelajaran inkuiri terbimbing. Dengan desain penelitian Posttest-Only Control Group Design [8] adalah sebagai berikut:

$$
\begin{array}{lll}
\mathrm{R} & \mathrm{X}_{1} & \mathrm{O}_{1} \\
\mathrm{R} & \mathrm{X}_{2} & \mathrm{O}_{2}
\end{array}
$$

Gambar 1. Desain Penelitian

Instrumen yang digunakan untuk mengukur pemahaman Interpretasi mahasiswa yaitu instrumen tes. Tes disusun dalam bentuk soal pilihan ganda yang terdiri atas 5 item pilihan jawaban. 1 pilihan benar dan 4 pilihan salah, jika jawaban benar point 1 dan salah poin 0 .

\section{HASIL DAN PEMBAHASAN}

\section{A. Hasil Penelitian}

Rekapitulasi Skor Pemahaman Interpretasi Pada Kelas dengan Menggunakan Model Inkuiri Bebas Termodifikasi dan Model Inkuiri Terbimbing ditunjukkan pada Tabel 1.

Tabel 1. Rekapitulasi Skor Pemahaman Interpretasi Pada Kelas dengan Menggunakan Model Inkuiri Bebas Termodifikasi dan Model Inkuiri Terbimbing.

\begin{tabular}{ccc}
\hline $\begin{array}{c}\text { Hasil Skor Hasil Belajar } \\
\text { Fisika }\end{array}$ & $\begin{array}{c}\text { Kelas Inkuiri Bebas } \\
\text { Termodifikasi }\end{array}$ & $\begin{array}{c}\text { Kelas Inkuiri } \\
\text { terbimbing }\end{array}$ \\
\hline Jumlah Sampel & 33 & 34 \\
\hline Rata-Rata & 7,12 & 5,74 \\
\hline Standar Deviasi & 2,29 & 1,79 \\
\hline Skor Maksimum & 10 & 9 \\
\hline Skor Minimum & 4 & 2 \\
\hline Skor Maksimum Ideal & 10 & 10 \\
\hline Skor Minimum Ideal & 0 & 0 \\
\hline
\end{tabular}

Adapun hasil yang diperoleh berdasarkan tingkat kategori pemahaman konsep interpretasi fisika mahasiswa pada kelas dengan menggunakan model inkuiri bebas termodifikasi dan inkuiri terbimbing dapat dilihat pada Tabel 2. 
Tabel 2. Interval Kategori Skor Pemahaman Konsep Interpretasi Fisika Kelas dengan Menggunakan Model Inkuiri Bebas Termodifikasi dan Model Inkuiri Terbimbing.

\begin{tabular}{cccccc}
\hline \multirow{2}{*}{ Interval } & \multicolumn{2}{c}{ Frekuensi } & \multicolumn{2}{c}{ Persentase (\%) } & Klasifikasi \\
\cline { 2 - 5 } & $\begin{array}{c}\text { Inkuiri Bebas } \\
\text { Termodifikasi }\end{array}$ & $\begin{array}{c}\text { Inkuiri } \\
\text { Terbimbing }\end{array}$ & $\begin{array}{c}\text { Inkuiri Bebas } \\
\text { Termodifikasi }\end{array}$ & $\begin{array}{c}\text { Inkuiri } \\
\text { Terbimbing }\end{array}$ & \\
\hline $9-10$ & 9 & 1 & 27,3 & 2,9 & Sangat baik \\
\hline $7-8$ & 10 & 10 & 30,3 & 29,4 & Baik \\
\hline $5-6$ & 11 & 11 & 33,3 & 32,4 & Sedang \\
\hline $3-4$ & 3 & 11 & 9,1 & 32,4 & Kurang \\
\hline $0-2$ & 0 & 1 & 0,0 & 2,9 & $\begin{array}{c}\text { Sangat } \\
\text { kurang }\end{array}$ \\
\hline
\end{tabular}

Data distribusi frekuensi kategorisasi skor pemahaman konsep interpretasi kelas dengan menggunakan model inkuiri bebas termodifikasi dan inkuiri terbimbing dapat digambarkan dalam histogram kategorisasi seperti yang ditunjukkan pada Gambar 2.

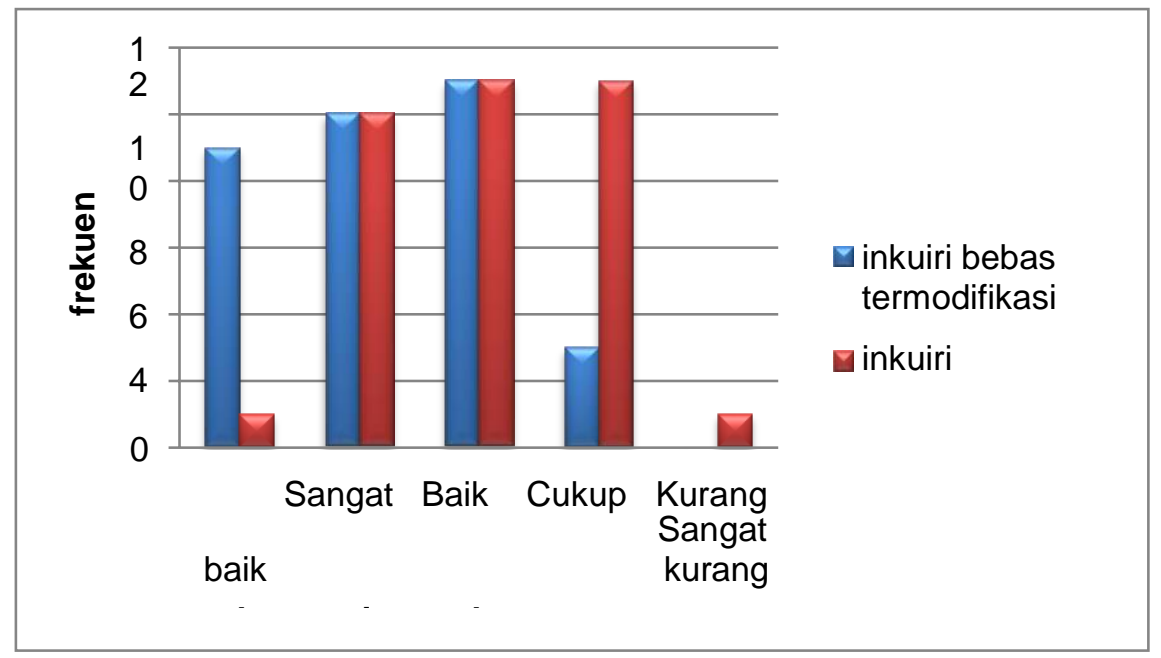

Gambar 2. Histogram Kategori Skor Pemahaman Interpretai

\section{B. Pembahasan}

Pada tabel 1 menunjukkan bahwa, pada kelas dengan menggunakan model inkuiri bebas termodifikasi skor pemahaman interpretasi diperoleh skor ratarata 7,17 , standar deviasi 2,29, skor maksimum 10, skor minimum 4. Sedangkan pada kelas dengan menggunakan model inkuiri terbimbing diperoleh skor rata-rata 5,74, standar deviasi 1,79, skor maksimum 9, skor minimum 2. Berdasarkan Tabel 2 dan Gambar 1, dengan jumlah 33 mahasiswa pada kelompok yang menggunakan model inkuiri bebas termodifikasi dan 34 mahasiswa pada kelas yang menggunakan inkuiri terbimbing, dapat ditunjukkan bahwa jumlah mahasiswa yang memiliki pemahaman interpretasi dengan menggunakan model inkuiri bebas termodifikasi dan inkuiri terbimbing berturut-turut, pada kategori sangat kurang sebanyak 0 dan 1 orang, kategori kurang 3 dan 13 orang, kategori sedang 11 dan 11 orang, kategori baik 10 dan 10 orang dan pada kategori sangat baik 9 dan 1 orang . 
Berdasarkan data-data yang diperoleh dapat disimpulkan bahwa pemahaman interpretasi mahasiswa dengan menggunakan inkuiri bebas termodifikasi lebih tinggi dibandingkan dengan menggunakan inkuiri terbimbing. Hal ini ditunjukkan pada kategori sangat kurang frekuensi mahasiswa pada kelompok yang menggunakan inkuiri bebas termodifikasi tidak ada sedangkan inkuiri terbimbing terdapat 1 orang, pada kategori kurang frekuensi mahasiswa pada kelompok dengan menggunakan inkuiri bebas termodifikasi lebih rendah dibandingkan dengan frekuensi mahasiswa dengan menggunakan model inkuiri terbimbing. Pada kategori sedang dan baik hanya terdapat selisih yang sangat kecil yaitu $0,9 \%$ dengan frekuensi mahasiswa dengan menggunakan model inkuiri bebas termodifikasi yang lebih tinggi. Sedangkan pada kategori baik frekuensi mahasiswa dengan menggunakan model inkuiri bebas termodifikasi lebih tinggi dibandingkan dengan frekuensi mahasiswa pada kelompok yang menggunakan model inkuiri terbimbing.

Kemampuan interpretasi yang melibatkan komunikasi, sebagai konfigurasi pemahaman ide yang memungkinkan memerlukan penataan kembali ide-ide ke dalam konfigurasi baru dalam pikiran mahasiswa. Hal ini, termasuk berpikir tentang kepentingan relatif dari ide-ide hubungan timbal balik dan relevansi untuk menggeneralisasi atau menjelaskan kedalam komunikasi sesungguhnya. Bukti dari kemampuan interpretasi mahasiswa yaitu kemampuan dalam menggeneralisasi, menyimpulkan atau kemampuan dalam meringkas. Model inkuiri terbimbing merupakan model yang membimbing mahasiswa dalam memecahkan permasalahan dan membuktikan hipotesis yang telah disusun sedangkan model inkuiri bebas termodifikasi memberikan kebebasan kepada mahasiswa untuk memecahkan dan membuktikan sendiri masalah yang ditemukan.

Berdasarkan teori belajar konstruktivis, secara garis besar keterkaitan prinsipprinsip konstruktivisme dalam proses pembelajaran yaitu (a) pengetahuan dibangun sendiri oleh mahasiswa baik secara personal maupun sosial. (b) mahasiswa aktif mengkonstruksi terus menerus sehinnga terjadi perubahan konsep menuju ke perubahan konsep yang lebih terperinci, lengkap, dan sesaui dengan konsep ilmiah. (c) dosen sebagai fasilitator, sekedar membantu menyediakan sarana dan mengendalikan situasi agar proses konstruksi mahasiswa berjalan lancar. (d) pengetahuan tidak semua dapat ditarnsfer dari dosen ke mahasiswa, kecuali hanya dengan keaktifan mahasiswa sendiri untuk belajar [9].

Berdasarkan pembahasan tersebut maka dapat diketahui bahwa model pembelajaran inkuiri bebas termodifikasi lebih kepada mendorong mahasiswa untuk mengkonstruksi sendiri konsepnya, mendorong mahasiswa untuk menggeneralisasi konsep yang diperoleh dari pembelajaran, sedangkan model inkuiri terbimbing masih mendapatkan bimbingan dari dosen secara terstruktur, sehingga kecendrungan mahasiswa untuk mandiri dalam mengkonstruk konsep yang ia miliki kurang, dilain sisi mahasiswa yang menemukan sendiri konsep yang sudah ada akan memberikan makna yang lebih baik dibandingkan dengan mahasiswa yang dibimbing untuk menemukan konsep yang telah ada, hal ini sejalan dengan teori belajar bermakna. Paparan ini menunjukkan bahwa kemampuan interpretasi mahasiswa lebih baik dengan menggunakan model inkuiri bebas termodifikasi daripada menggunakan model pembelajaran inkuiri terbimbing Hantersebut identic dengan penelitian sebelumnya bahwa penerapan model pembelajaran inkuiri terbimbing untuk meningkatkan aktivitas dan hasil belajar pada materi pembelajaran peserta didik, hal 
ini dapat dikarenakan proses KBM model inkuiri terbimbing yang telah dilaksanakan memberikan kebebasan dalam mengkonstruksi pemikiran dan penemuan konsep maka siswa lebih dapat memahami materi untuk meningkatkan hasil belajar dan aktivitas siswa.

\section{SIMPULAN DAN SARAN}

Berdasarkan hasil penetilian dan pembahasan yang telah dipaparkan pada bab sebelumnya, maka dapat ditarik kesimpulan bahwa pemahaman konsep interpretasi fisika melalui model pembelajaran inkuiri terbimbing mahasiswa Jurusan Pendidikan Fisika UIN Alauddin Makassar sedang dan pemahaman konsep interpretasi fisika melalui model pembelajaran inkuiri bebas termodifikasi mahasiswa Jurusan Pendidikan Fisika UIN Alauddin Makassar sedang serta terdapat perbedaan pemahaman konsep interpretasi fisika antara kelompok mahasiswa yang diajar dengan menggunakan inkuiri bebas termodifikasi dengan kelompok mahasiswa yang diajar dengan inkuiri terbimbing.

Sehubungan dengan hasil yang diperoleh dalam penelitian ini, maka penulis mengajukan beberapa saran bahwa penelitian ini memberikan data bahwa kemampuan interpretasi mahasiswa lebih tinggi jika menggunakan model pembelajaran inkuiri bebas termodifikasi dibandigkan menggunakan model pembelajaran inkuiri terbimbing, sehingga peneliti menyarankan untuk menggunakan model ini dalam proses pembelajaran jika pencapaian yang diinginkan adalah kemampuan menginterpretasikan dan untuk peniliti atau pendidik, hasil penelitian ini bisa dijadikan sebagai referensi tambahan dalam mengambil keputusan penggunaan model pembelajaran, terutama saat ingin mengukur pemahaman konsep peserta didik serta jika ingin menggunakan model pembelajaran ini, sebaiknya perhatikan dengan baik kemampuan siswa dan fasilitas yang tersedia perlu dipahami pula bahwa kemampuan peserta didik diperlukan agar berinkuiri bisa berjalan dengan baik sedang untuk fasilitas juga perlu diperhatikan terutama ketersediaan alat dan bahan yang akan digunakan saat berikuiri baik di laboratorium maupun di alam bebas.

\section{DAFTAR PUSTAKA}

[1] Abdullah A. H. (2017). Pencapaian Matematik TIMSS 1999, 2003, 2007, 2011 Dan 2015: Di Mana Kedudukan Malaysia Dalam Kalangan Negara Asia Tenggara?. Malaysian Journal Of Higher Order Thinking Skills In Education.

[2] Arsyad, M. (2019). Penerapan Metode Inkuiri Dalam Peningkatan Hasil Belajar IPS Pada Pokok Bahasan Kegiatan Ekonomi Penduduk Siswa Kelas V SD Inpres 10/73 Welado Kabupaten Bone. JIKAP PGSD: Jurnal Ilmiah Ilmu Kependidikan, 3 (2), 92-93

[3] Danoebroto, S. W. (2015). Teori Belajar Konstruktivis. P4TK Matematika.

[4] Hamalik, O. (2011). Doc 17. In Proses Belajar Mengajar.

[5] Hastjarjo, T. D. (2019). Rancangan Eksperimen-Kuasi Quasi-Experimental 
Design. Buletin Psikologi.

[6] Patta, R. (2017). Penerapan Model Pembelajaran Inkuiri Untuk Meningkatkan Hasil Belajar Ipa Siswa Kelas V SD Inpres 6/75 Ta' Kecamatan Tanete Riattang Kabupaten Bone. JIKAP PGSD: Jurnal Ilmiah Ilmu Kependidikan.1 (1),40-49

[7] Nur'Azizah, H. (2016). Pengaruh Model Pembelajaran Inkuiri Terbimbing terhadap Kemampuan Berpikir Kritis Siswa pada Materi Energi Bunyi. Jurnal Pena Ilmiah, 1 (1), 51-60

[8] Wayan Sadia, P. D. M. Dan I Made, P D. Y. (2013). "Pengaruh Implementasi Model Pembelajaran Inkuiri Terbimbing Terhadap Kemampuan Pemahaman Konsep Dan Literasi Sains Siswa Kelas X Sma Pgri 1 Amlapura. Jurnal Administrasi Pendidikan, 4 (1), 1-11

\{9\} Tangkas, I. (2012). Pengaruh Implementasi Model Pembelajaran Inkuiri Terbimbing terhadap Kemampuan Pemahaman Konsep dan Keterampilan Proses Sains Siswa Kelas X Sman 3 Amlapura. Jurnal Pendidikan dan Pembelajaran IPA Indonesia, 2 (1)

[10] Trianto. (2012). Mendesain Model Pembelajaran Inovetif-Progresif Konsep, Landasan dan Implementasinya pada KTSP.Jakarta: Kencana. 